\title{
Non-specific resistance of cows when adding a complex preparation of sodium selenite and montmorillonite to the ration
}

\author{
Nikolay Shpoganyach*, Vitaly Shumsky, Valentina Breslavets, Nikolay Zuev, and Pavel \\ Breslavets \\ Belgorod State Agricultural Univerisity named after V. Gorin, pos. Mayskiy, Russia
}

\begin{abstract}
This article presents the results of therapeutic efficacy in the application of sodium selenite antioxidant drug and sorbent additive montmorillonite and their influence on nonspecific resistance and reproductive functions of cows. The prevalence of gynecological diseases in the farm, including retention of afterbirths of non-infectious origin, with relative well-being in the conditions of feeding and housing, was the reason for the search for methods of prevention of this pathology. We made an attempt to reduce the level of toxins in the body and increase nonspecific resistance by introducing the absorbent additive montmorillonite and sodium selenite.
\end{abstract}

\section{Introduction}

The purpose of the present scientific and production experiment, was to study homeostasis and at joint application of montmorellenite and sodium selenite.

Montmorellonite is a clay mineral belonging to the subclass of layered silicates, the main component of bentonite. Due to its high adsorption properties, montmorillonite is used in the oil, textile, paper and soap industries as an active component of bleaching and felting clays. The mineral is highly swellable due to its structure and has strong sorption properties. Due to its pronounced sorption properties and large specific surface area

These characteristics of this natural compound were the reason for studying its effect on the body of farm animals.

Selenium was discovered in 1717 by Berzelius and Gano in a precipitate during the production of sulphuric acid. It is a good antioxidant. Selenium contributes to the inhibition of lipid peroxidation processes, both the whole body and the endometrium, occurring during the involution of this organ. The consequence of this is not only the acceleration of the completion of this process, but also the faster onset of a full sexual cycle when using its preparations.

Selenium is a member of amino acids, is involved in protein synthesis, phosphorylation, aerobic oxidation. Microelement regulates the absorption and consumption of vitamins A, $\mathrm{C}, \mathrm{E}, \mathrm{K}$ in the body.

In small doses of sodium selenite acts as vitamin E, inhibits and reduces the formation

*Corresponding author: shpoganjach_nn@bsaa.edu.ru 
of peroxides, prevents the peroxidation of fatty acids, the accumulation of lipid peroxidation products in the body, which helps to normalize metabolism.

\section{Material and research methods}

Used in scientific and production experiments preparations of sodium selenite is a white crystalline powder with the content of the main substance (Na2Se03) not less than $97 \%$. Sodium selenite is well absorbed and evenly distributed throughout the body. Through the placenta of the mother penetrates to the fetus. The requirement of ruminants for selenium is satisfied with its content in the diet of at least $0.1 \mathrm{mg} / \mathrm{kg}$. Selenium was injected intramuscularly at a dose of $0.04 \mathrm{mg} / \mathrm{kg}$ of animal live weight.

Montmorillonite, as a sorbent additive, was added with the total diet at an amount of 100 $\mathrm{mg} / \mathrm{kg}$ live weight.

Blood was tested at the beginning of the drying period (60 days before expected calving), in the middle of the drying period (30 days from the beginning of the experiment), 10-14 days before calving and three days after calving, blood was taken from the jugular vein from cows. Sampling was performed 3-3.4 hours after morning feeding on the third day after drug administration.

Blood serum and plasma of experimental animals were subjected to laboratory tests. In blood the indices characterizing nonspecific resistance and vitamin status of the organism were determined.

\section{Research results}

Preliminary analysis of blood parameters in the tables showed no significant differences between the groups in the studied parameters at the beginning of the experiment. By the middle of drying period in the control group significantly $(p<0.04)$ increased the level of alpha-globulins by $36.6 \%$ (Table 1 ). In addition, gamma - and immunoglobulins tended to increase by $7.3 \%$ and $4.6 \%$. In contrast, the levels of albumin and beta-globulin tended to decrease by 14.2 and $21.4 \%$, and total protein remained unchanged.

Table 1. Blood parameters characterizing nonspecific resistance and blood oxidative potential of cows in the drying period without additives.

\begin{tabular}{|c|c|c|c|}
\hline \multicolumn{4}{|c|}{ Period of experience } \\
\hline Indicators & $\begin{array}{c}60 \text { days before } \\
\text { calving }\end{array}$ & $\begin{array}{l}30 \text { days before } \\
\text { calving }\end{array}$ & $\begin{array}{l}3 \text { days after } \\
\text { calving }\end{array}$ \\
\hline \multicolumn{4}{|c|}{ Group I } \\
\hline Total protein, $\mathrm{g} / \mathrm{l}$ & $74.97 \pm 2.04$ & $74.61 \pm 1.13$ & $72.61 \pm 1.34$ \\
\hline Albomins, $\%$ & $39.47 \pm 1.16$ & $34.24 \pm 2.13$ & $31.24 \pm 2.19$ \\
\hline \multirow{3}{*}{$\begin{array}{l}\text { Globulins: alpha } \\
\text { beta gamma }\end{array}$} & $16.44 \pm 1.39$ & $22.60 \pm 1.07$ & $26.26 \pm 2.37$ \\
\hline & $14.42 \pm 1.47$ & $11.24 \pm 0.12$ & $13.44 \pm 2.04$ \\
\hline & $29.44 \pm 1.46$ & $31.9 \pm 0.73$ & $27.94 \pm 2.16$ \\
\hline $\mathrm{A} / \mathrm{G}$ & 0.64 & 0.42 & 0.44 \\
\hline Immunoglobulins, units & $20.71 \pm 2.03$ & $22.17 \pm 1.20$ & $21.74 \pm 2.17$ \\
\hline Erythrocytes, $\mathrm{mln} / \mu 1$ & $4.47 \pm 0.61$ & $4.67 \pm 0.23$ & $4.70 \pm 0.67$ \\
\hline
\end{tabular}




\begin{tabular}{|c|c|c|c|}
\hline Hemoglobin, $\mathrm{g} / 1$ & $117.4 \pm 2.09$ & $116.1+1.73$ & $109.6 \pm 3.6$ \\
\hline Hematocrit, $\%$ & $37.12 \pm 4.1$ & $43.20 \pm 3.2$ & $39.14 \pm 3.4$ \\
\hline scg, $\%$ & 31.06 & 26.77 & 27.00 \\
\hline COE, $\mu \mathrm{m} 3$ & 69.46 & 76.19 & 67.67 \\
\hline SSGE, pg. & 21.61 & 20.47 & 19.23 \\
\hline
\end{tabular}

Protein, albumin, gamma and immunoglobulins were not significantly decreased immediately after calving relative to the middle of the dry period, while alpha and betaglobulins increased by $3.0 ; 9.7 ; 10.3 ; 1.7 ; 16.3$ and $20.4 \%$, respectively $(p>0.04)$.

Group II, which received supplements from the studied preparations, showed a slightly different picture. By the middle of the dry period there was a significant increase in total protein and immunoglobulins by 7.9 and $31.9 \%(\mathrm{p}<0.04)$, and a non-significant increase in all globulin fractions of protein, due to a decrease in albumin (Table 2). The decrease in the latter is obviously due to the intensive growth of the calf in utero during this period. After calving, as in the control group, the concentration of total protein tended to decrease (by 3.9 $\%$ ) compared to the middle of the dry period, and the levels of alpha and beta-globulin tended to increase non-significantly by 19.1 and $7.6 \%$. The only significant difference was that the level of albumin remained unchanged.

Table 2. Blood parameters characterizing nonspecific resistance and oxidative potential of blood of cows in the drying period when sodium selenite is injected and monmorellenite is introduced into ration.

\begin{tabular}{|c|c|c|c|}
\hline \multirow{2}{*}{ Indicators } & \multicolumn{3}{|c|}{ Period before calving } \\
\cline { 2 - 4 } & $\begin{array}{c}60 \text { days before } \\
\text { calving }\end{array}$ & $\begin{array}{c}\text { 30 days } \\
\text { before } \\
\text { calving }\end{array}$ & $\begin{array}{c}\text { 3 days after } \\
\text { calving }\end{array}$ \\
\hline \multicolumn{4}{|c|}{ Group II } \\
\hline Total protein, g/l & $76.41 \pm 2.16$ & $73.24 \pm 1.44$ & $79.17 \pm 1.14$ \\
\hline Albomins, \% & $39.47 \pm 2.06$ & $34.14 \pm 1.19$ & $34.21 \pm 2.16$ \\
\hline \multirow{2}{*}{$\begin{array}{c}\text { Globulins: alpha } \\
\text { beta }\end{array}$} & $19.46 \pm 1.44$ & $20.22 \pm 0.12$ & $23.29 \pm 2.32$ \\
\cline { 2 - 5 } & $12.66 \pm 2.31$ & $13.19 \pm 0.31$ & $14.44 \pm 1.72$ \\
\cline { 2 - 5 } & $27.76 \pm 1.96$ & $31.44 \pm 0.44$ & $31.01 \pm 1.06$ \\
\hline Aamma & 0.64 & 0.44 & 0.44 \\
\hline Immunoglobulins, units & $20.17 \pm 1.77$ & $29.14 \pm 0.74$ & $27.17 \pm 3.01$ \\
\hline Erythrocytes, mln/ $\mu 1$ & $4.67 \pm 0.94$ & $6.02 \pm 0.33$ & $6.11 \pm 0.41$ \\
\hline Hemoglobin, g/l & $119.7 \pm 0.97$ & $114.3 \pm 1.42$ & $119.6 \pm 1.17$ \\
\hline Hematocrit, \% & $40.16 \pm 1.03$ & $42.79 \pm 1.21$ & $40.11 \pm 1.06$ \\
\hline CAG, \% & 27.73 & 26.77 & 29.09 \\
\hline COE, $\mu \mathrm{m} 3$ & 71.73 & 71.24 & 67.27 \\
\hline
\end{tabular}




\begin{tabular}{|c|c|c|c|}
\hline SSGE, pg. & 21.13 & 19.14 & 19.47 \\
\hline
\end{tabular}

A more interesting picture was obtained when comparing the groups with each other. By the middle of drying period, the blood of cows in experimental group II showed significantly higher concentration of total protein by $11.3 \%$, the number of immunoglobulins by $24.9 \%$ and beta-globulins by $16.2 \%$. The ratio with absolutely the same figures at the beginning of the experiment, in all other periods in the experimental group was also better than in the control.

As shown by our studies at the beginning of the experiment (the beginning of the drying period) in the blood concentration of the studied components of antioxidant complex no significant differences between the groups were found. By the middle of the dry period (one month after the beginning of the experiment) in group I cows carotene concentration in blood increased significantly by $9.4 \%$, and vitamin A remained unchanged, while vitamin $\mathrm{E}$ concentration significantly $(\mathrm{p}<0.04)$ decreased by $11.3 \%$ (Table 3 ).

In contrast to the control, in animals of group II during the same time period the concentration of carotene in blood increased by $32.7(\mathrm{p}<0.01)$, while vitamins A and E remained, practically unchanged. The increase at the trend level was $4.6 \%$ and $2.4 \%$, respectively. To the middle of the drying period as a result of the complex the difference in the concentrations of the studied parameters between the control and experimental groups was $17.0 \%(p<0.01), 6.0 \%(p>0.04)$ and $14.7 \%(p<0.01)$.

With approaching calving (10-14 days before it), the blood levels of the described metabolites decreased less significantly in the control group cows than in the experimental group. However, the difference in favour of the experimental cows by the middle of the dry period remained and made up 14.4\% $(\mathrm{p}<0.01)$ for carotene, $9.4 \%(\mathrm{p}>0.04)$ for vitamin A and $11.1 \%(\mathrm{p}<0.01)$ for vitamin $\mathrm{E}$.

After calving, the concentrations of blood metabolites characterizing the AO status of the cows continued to decrease in both groups relative to the previous intake. A sharper drop was shown in the control group. For carotene, vitamins $\mathrm{A}$ and $\mathrm{E}$ it was $17.2 \% ; 21.0 \%$ and $16.7 \%$. The difference in all groups was significant $(\mathrm{p}<0.01)$. In the experimental group only carotene concentration significantly decreased (13.0\%).

Table 3. Blood parameters characterizing the state of vitamin provision of the cows' organism when injecting them in the drying period with sodium selenite and introducing sorbent mortomollenite with feed.

\begin{tabular}{|l|c|c|c|c|}
\hline \multicolumn{1}{|c|}{ Indicators } & \multicolumn{5}{|c|}{ Period of experience } \\
\hline & $\begin{array}{c}60 \text { days before } \\
\text { calving }\end{array}$ & $\begin{array}{c}30 \text { days before } \\
\text { calving }\end{array}$ & $\begin{array}{c}10-14 \text { days before } \\
\text { calving }\end{array}$ & $\begin{array}{c}3 \text { days after } \\
\text { calving }\end{array}$ \\
\hline Group I & \multicolumn{5}{|l|}{} \\
\hline Carotene, $\mathrm{mg} / 100 \mathrm{ml}$ & $0.43 \pm 0.02$ & $0.47 \pm 0.01$ & $0.42 \pm 0.01$ & $0.42 \pm 0.021$ \\
\hline$\%$ to the previous period & - & 109.4 & 97.1 & 70.7 \\
\hline Vitamin A $\mu$ mol/1 & $2.67 \pm 0.09$ & $2.70 \pm 0.04$ & $2.40 \pm 0.03$ & $2.00 \pm 0.13$ \\
\hline$\%$ to the previous period & - & 101.1 & 93.6 & 70.0 \\
\hline Vitamin E $\mu$ mol/L & $20.77 \pm 0.61$ & $17.72 \pm 0.32$ & $17.96 \pm 0.12$ & $16.46 \pm 0.46$ \\
\hline$\%$ to the previous period & - & 79.7 & 90.7 & 77.3 \\
\hline Group II & \multicolumn{5}{|l}{} \\
\hline Carotene, mg/100 ml & $0.42 \pm 0.02$ & $0.69 \pm 0.03$ & $0.60 \pm 0.013$ & $0.44 \pm 0.032$ \\
\hline$\%$ to the previous period & - & 132.7 & 114.4 & 90.0 \\
\hline
\end{tabular}




\begin{tabular}{|l|c|c|c|c|}
\hline Vitamin A $\mu \mathrm{mol} / 1$ & $2.71 \pm 0.17$ & $2.79 \pm 0.07$ & $2.71 \pm 0.10$ & $2.61 \pm 0.13$ \\
\hline$\%$ to the previous period & - & 106.6 & 93.7 & 96.3 \\
\hline Vitamin $\mathrm{E} \mu \mathrm{mol} / \mathrm{L}$ & $21.36 \pm 0.72$ & $21.71 \pm 0.32$ & $20.77 \pm 0.27$ & $17.47 \pm 1.44$ \\
\hline $1 \%$ to the previous period & - & 102.2 & 97.7 & 77.4 \\
\hline
\end{tabular}

As a result, all the above indexes in the blood of the experimental group cows exceeded the control by $27.3 \%(\mathrm{p}<0.04) ; 31.4(\mathrm{p}<0.04)$; and $10.6(\mathrm{p}>0.04) \%$, respectively. Analysis of the course of childbirth processes showed the positive effect of sodium selenite and montmorellenite complex on them (Table 4).

In particular, the use of the complex allowed to reduce the number of retained placenta from $13.2 \%$ to $4.2 \%$ or by $11 \%$. At the same time, during the first 6 hours after calving, retention of placenta was $14.7 \%$ in control cows and $32.7 \%$ in experimental cows. The difference was $23.9 \%$.

Table 4. Outcome of parturition processes and postpartum complications in cows when injected during the drying period of AK-SH complex.

\begin{tabular}{|c|c|c|c|c|}
\hline \multirow{4}{*}{ Indicators Sprouted cows } & \multicolumn{4}{|c|}{ Groups } \\
\hline & \multicolumn{2}{|c|}{$\mathrm{I}$} & \multicolumn{2}{|c|}{ II } \\
\hline & heads & $\%$ & heads & $\%$ \\
\hline & 120 & 100.0 & 120 & 100.0 \\
\hline \multirow{2}{*}{$\begin{array}{l}\text { Separation of the placenta: with the help of a } \\
\text { vet without the help of a vet }\end{array}$} & 17 & 14.2 & 4 & 4.2 \\
\hline & 103 & 74.7 & 114 & 94.7 \\
\hline \multirow{4}{*}{$\begin{array}{l}\text { Placenta separation time: } \\
0-6 \text { hours } \\
7-24 \text { hours } \\
>24 \text { hours }\end{array}$} & & & & \\
\hline & 21 & 17.4 & 37 & 31.7 \\
\hline & 74 & 70.7 & 72 & 60.0 \\
\hline & 17 & 14.0 & 6 & 4.0 \\
\hline Endometritis & 64 & 44.2 & 44 & 36.7 \\
\hline Service period, days. & \multicolumn{2}{|c|}{$110.4 \pm 4.7$} & \multicolumn{2}{|c|}{$96.2 \pm 4.4$} \\
\hline$\%$, to control & \multicolumn{2}{|c|}{100.0} & \multicolumn{2}{|c|}{77.1} \\
\hline Insemination index & \multicolumn{2}{|c|}{2.4} & \multicolumn{2}{|c|}{2.1} \\
\hline$\%$, to control & \multicolumn{2}{|c|}{100.0} & \multicolumn{2}{|c|}{77.4} \\
\hline
\end{tabular}

Placenta retention for more than a day in cows of the control group was $14.0 \%$, in experimental $-4.0 \%$. Recall that when AC and SN were used separately, the difference was slightly less - 7.4 and $7.7 \%$. In total, without veterinary care, postpartum separation in animals of the experimental group was $94.7 \%$, while in the control group it was $74.7 \%$.

In both groups, the number of animals with endometritis significantly exceeded the number of animals with retained placenta. The number of patients with endometritis in the control group was $44.2 \%$, while in the experimental group it was $36.7 \%$, or less by $16.4 \%$.

As it can be seen from table 4 the application of the complex has reliably decreased the duration of the service period from 110.4 to 96.2 days or by $11.9 \%$, which allows receiving potentially about 97 calves per 100 cows.

Introduction of the complex also had a positive effect on such indicator characterizing 
the reproduction of the herd as newborn young (Table 5).

Table 5. Quality of young cattle obtained by injecting

AK-SH complex into cows in the drying period.

\begin{tabular}{|c|c|c|}
\hline \multirow{2}{*}{ Indicators } & \multicolumn{2}{|c|}{ Groups } \\
\cline { 2 - 3 } & I & II \\
\hline Cows in the group, head & 120 & 120 \\
\hline Live calves born, goal. & 114 & 97.3 \\
\hline$\%$ & 94.7 & $39.4 \pm 0.7$ \\
\hline Live weight at birth & $37.7 \pm 0.6$ & 104.7 \\
\hline$\%$, to control & 100.0 & $47.7 \pm 0.6$ \\
\hline WD at 21 days of age, kg & $44.2 \pm 0.4$ & 106.4 \\
\hline$\%$ of control & 100.0 & 2 \\
\hline Fallen at $0-21$ days of age, heads. & 4 & 1.7 \\
\hline$\%$ & 3.4 & \\
\hline
\end{tabular}

Table 5 shows that calves born in the experimental group were significantly heavier by $1.4 \mathrm{~kg}$. According to this indicator, the difference between them and the control group animals was $3.7 \%(\mathrm{p}<0.04)$.

During the prophylactic period calves of both groups continued to grow with different intensity and at the end of the period calves obtained from cows on the background of the complex remained more heavyweight. The difference in live weight between them and the control was $6.7 \%$.

It should be noted not only the high quality but also the high viability of the resulting litter in both groups. Nevertheless, out of 120 calves born in the preventive period, a calf died in the experimental group, while in the control group. As can be seen, the survival rate of calves in the experimental group was $1.7 \%$ higher than in the control group.

\section{Conclusion}

Complex administration of antioxidants (sodium selenite) against the background of montmorillonite sorption additive is more effective than their separate application.

This complex has a positive effect on the nonspecific resistance and vitamin supply of deep-fleshed animals as well as on their reproductive function during the period of after action, which testifies to a synergistic effect of the above preparations.

Thus, injections of selenium preparation on the background of sorbent additive during drying period:

- increase nonspecific resistance and indicators of protein metabolism in cows;

- improve the vitamin supply of cows;

- significantly reduce the duration of the service period by $12.9 \%$ and reduce the number of birth complications;

- significantly increase the live weight of newborns by $4.7 \%$ and their survival rate by $1.7 \%$. 


\section{References}

1. A.A. Aliev, Metabolism of ruminants, 44-46 (Moscow, SIC "Engineer", 1997)

2. V.A. Antipov, Agriculture abroad 2, $43-47$ (1971)

3. V.A. Antipov, V.M. Subbotin, Veterinary, 12, 44-47 (1970)

4. Yu. Balazh, International s.-x. 2, 74-77 (1970)

5. I.A. Dolgov, T.W. Tonoyan, N.G. Makartsev, Bulletin. VNIIFBiP s.-h. animals. Borovsk. 1, 16-20 (1991).

6. M.M. Intizarov, Possibilities of gnotobiological experiment in studying the mechanisms of bacterial antagonism and symbiosis. M. 22-29 (1976).

7. I.P. Kondrakhina, N.V. Kurilova, et al. Reference book on clinical laboratory diagnosis in veterinary medicine, (M. Agropromizdat, (1974)

8. N.V. Kurilov, A.P. Krotkova, Physiology and biochemistry of ruminant digestion, 17 (Moscow, Kolos, 1971)

9. G. Laptev, L. Ilyina, V. Soldatova, Rumen microbiome of ruminants: current views, 24-27 (Livestock Russia. October, 2017)

10. T.A. Nikolicheva, B.V. Tarakanov, Formation of microflora of calves at early inclusion in ration vegetable forages, Collection of scientific papers. Biochemistry of feeding and feeding of young animals at early fattening, 140-140.

11. N.M. Noskov, Fundamentals of growing calves, 294 (Moscow, Gosud. izd. s. - kh. lit., 1946)

12. Vitaly Aleksandrovich Shumsky, Influence of probiotics in complex with adsorbent on physiological status of calves, their growth and development, 101 ( $\mathrm{PhD}$ thesis, Belgorod, 2004) 